\title{
$\angle$ Research Square

\section{The Influence of Family Structure and Adult Attachment Style on Theft Behaviors in Men: a Case-Control Study}

\section{Xu Wang}

Sichuan University West China Hospital

Jiajun Xu ( $\nabla$ xujiajun@wchscu.cn )

Mental Health Center of West China Hospital, Sichuan University

\section{Research article}

Keywords: family structure, adult attachment, theft, case-control

Posted Date: September 20th, 2021

DOl: https://doi.org/10.21203/rs.3.rs-889578/v1

License: (c) (1) This work is licensed under a Creative Commons Attribution 4.0 International License.

Read Full License 


\section{Abstract}

Background: Theft has leaded to significant costs to commerce and legal system, but its psychological mechanisms and risk factors are barely explored. This study aims to investigate the influence of family structure and adult attachment style on theft behaviors in men.

Methods: 257 men with a conviction for theft (theft group) and 405 male college students (control group) were interviewed with Experiences in Close Relationships Scale and a general questionnaire about sociodemographic information, family structure and criminal records.

Results: Compared with control group, long-term residency, family economic situation, number of siblings, father's presence before 5 years old, parents' state of existence and parents' marital status of theft group were significantly different $(P<0.05)$. Living in urban area, from relatively poor family, not living with father before 5 years old and parents not divorced increased the likelihood of theft in men $(P<0.05)$. While father not alive and having no siblings decreased the likelihood of theft in men $(P<0.05)$. Then theft group was further divided into first offender group and recidivist group. First offender group had a significantly higher proportion of living with mother/father before 5 years old and father alive than recidivist group $(P<0.05)$. Not living with mother before 5 years old and father not alive increased the possibility of multiple thefts, while preoccupied attachment decreased such possibility $(P<0.05)$.

Conclusions: This study suggested that risk factors for theft and multiple thefts were different. A variety of targeted strategies related to family structure and attachment styles are needed to prevent theft from occurring and reoccurring.

\section{Background}

According to data released by the National Bureau of Statistics, the rate of theft crimes in China gradually increased and accounted for two-thirds of all crimes (Liu \& Gao, 2018). Theft, the crime of stealing and one kind of antisocial behaviors, has leaded to significant costs to commerce and legal system. It is believed theft behaviors are associated with emotional and behavioral disorders such as kleptomania and antisocial behaviors, as well as a direct motive to obtain economic benefits (Prospero-Luis et al., 2017; Blum et al., 2018).

Prior researches on theft behaviors have mainly focused on kleptomania (Brazil et al., 2018; Zhang et al., 2018). Individuals with kleptomania commit multiple thefts because of an irresistible urge to steal items that are not needed for personal use or for monetary value, following by an intense feeling of gratitude or relief after (American Psychological Association, 2013), which can be quite different from theft with a direct motive to obtain economic benefits (Sipowicz \& Kujawski, 2018). However, persons with charges or convictions for theft are not routinely assessed for kleptomania in China, so whether their theft behaviors are consequences of a mental illness or economic reasons is unclear. 
Theft behaviors are also considered to be related to family structures and interpersonal problems with family members, especially with parents (Lee et al., 2015). Wang et al (2011) found that adolescent's antisocial behaviors differ due to changes in family structures and interactions between adolescents and parents. Interaction and emotional connection formed between children and their early attachment figures, namely attachment style, determined one's self-cognitive development and predicted externalizing and internalizing problems, such as delinquency and anxiety (Ainsworth, 1982; Bowlby, 1982; Fearon, 2010; Groh et al., 2014 ). Children from single-parent families had higher occurrence of antisocial behaviors (Liu et al., 2017). Even though theft is considered to be an antisocial behavior in general, it shows a different development trajectory from violent antisocial behaviors such as attack and destruction. Barker et al. (2007) took theft and physical violence, two common antisocial behaviors in children and adolescents, as an example. Through a long-term cohort tracking, they found that violent behaviors decreased with age, while theft behaviors increased with age and reached its peak in early adulthood. In summary, family structure and adult attachment style are closely related to antisocial behaviors (Murray et al., 2018; Sobotkova et al., 2013), but the impact of them on theft is still inconclusive.

Many researches have investigated the psychological mechanisms behind general antisocial behaviors (Cheung, 2014; Weng et al., 2016), however, rather less are focused on theft. Even among those theft related researches, the main topics were judicial characterization and sentencing of theft crimes in China $(\mathrm{Hu}, 2019)$. Psychological mechanisms and risk factors behind theft are barely explored. A comprehensive examination of psychological and family domains can help with profound understanding of theft and hence advance rehabilitation programs for theft offenders.

In order to explore the correlation between family structure and adult attachment style and theft behaviors, this study compared men with a conviction of theft and male college students in western China. Results are now reported as follows.

\section{Methods}

\section{Setting and Participants}

First part of this study was conducted in two prisons located in Jiangsu province and Sichuan province after mental heath lectures for male prison inmates with a conviction for theft. Questionnaires were sent to those who attended the lectures. Informed consent and inclusion and exclusion criteria were printed at the top of the questionnaire. Participants who did not agree to participate or did not meet the criteria were advised to stop answering the following questions. Inclusion criteria consisted of: (1) people aged 18 and over, (2) with normal cognitive function, (3) had no serious physical diseases, (4) and signed informed consent. Exclusion criteria comprised the following: (1) people with previous history of epilepsy, (2) and/or previous history of brain trauma, (3) and/or previous or current diagnosis of mental disorders in the DSM-V. 
To compare the results of the questionnaires in the group of men with a conviction for theft (theft group) and the general population, we recruited a control group in the second part of this study. Since the theft group was made up of men in early adulthood, 420 male college students were recruited from two universities in Sichuan province as a control group at a ratio of 2: 3 to balance the gender and age distribution. The inclusion and exclusion criteria of control group were basically the same as the theft group, except that "people with no previous criminal record" was added as an exclusion criterion.

This study is a case-control design, and frequency matching or individual matching between groups is not required.

\section{Data Collection}

Data were collected from December 2020 to January 2021. When written informed consent was granted, we explained questionnaires to participants. Participants answered questions about their sociodemographic data and criminal records and completed a standardized questionnaire about adult attachment style. When participants did not understand some questions, they were specifically instructed, but no suggestive language was used. Upon completion, the questionnaire was withdrawn. In total, 280 questionnaires of the theft group were sent out and 257 valid questionnaires were retrieved. 420 questionnaires of the control group were issued and 405 valid questionnaires were retrieved.

\section{Ethical Statement}

Ethical approval was granted by the Medical Ethics Committee of West China Hospital, Sichuan University before data collection. All participants were informed of contents and data usage of the study. Written informed consent was obtained before answering any question.

\section{Measurement}

\section{The General Questionnaire}

A general questionnaire was used to collect participants' socio-demographic data and criminal records, including questions about age, long-term residency (urban area, suburb area, remote area), family economic conditions (well-off, average, relatively poor, very poor), having siblings or not (both biological parents in common), lived with mother/father before 5 years old or not (one present and the other absent), mother/father alive or not, parents divorced or not, and the number of arrests for theft (one, more than one).

\section{The Experiences in Close Relationships Scale (ECR)}

Experiences in Close Relationships Scale (ECR) (Brennan et al., 1998) is a self-reported questionnaire designed by Brennan et al. on adult romantic attachment style. Li Tonggui et al. (2006) translated it into a Chinese version and validated in Chinese cultural context. Although the initial ECR was anchored in relation to "my (romantic) partner", it was reworded with "the person who I think is close " for this study. 
There are 36 items in the ECR, and each item is rated by respondents using a seven-point Likert scale, indicating their level of agreement.

There are two dimensions of ECR: attachment-related anxiety and avoidance. Attachment-related anxiety measures the anxiety level of individuals who expect to build an intimate relationship with particular others, but are also afraid of being rejected and abandoned (Fraley et al., 2015). Attachment-related avoidance dimension reflects individual's fear of intimacy and the degree of discomfort towards approaching and relying on others, which is manifested as indifference and avoidance of social and interpersonal relationships (Fraley et al., 2015). The two dimensions are relatively independent and have no significant correlation. The higher the dimensional score, the stronger the degree of individual attachment anxiety and attachment avoidance. The Cronbach's a coefficient of avoidance dimension of the Chinese version of ECR is 0.82 and that of the anxiety dimension is 0.77 . The scale has good structural validity and content validity. After assessing the dimension of attachment, Fisher's linear discriminant formula was used to convert two dimensions into four adult attachment styles: secure (low anxiety, low avoidance), preoccupied (high anxiety, low avoidance), dismissing (low anxiety, high avoidance) and fearful (high anxiety, high avoidance) (Bartholomew \& Horowitz, 1919).

\section{Data Analysis}

Data entry and statistical analysis were performed using SPSS 19.0 software. The difference in sociodemographic characteristics, family structures and adult attachment styles between groups (theft group versus control group, first offender group versus recidivist group) were compared with $t$ tests for continuous variables and Chi-square tests for categorical variables. Binary logistic regression analysis was conducted to identify factors associated with theft behaviors. All effects referred to as statistically significant are associated with two-tailed $P$ values less than 0.05 .

\section{Results}

\section{Comparison Between Theft Group and Control Group}

Comparison of descriptive statistics for socio-demographic characteristics, family structures and adult attachment styles of theft group (TG) and control group (CG) were conducted and results were presented in Table 1.

There was no significant difference in age, living with mother before 5 years old and adult attachment styles between two groups ( $P>0.05$ ). However, participants' long-term residency, family economic situation, number of siblings, father's presence before 5 years old, parents' state of existence and parents' marital status were significantly different between TG and OG $(P<0.05)$.

\section{Risk Factors for Theft}

All variables with $p<0.05$ were candidate parameters for inclusion in the subsequent logistic regression analysis. As for adult attachment styles, even though there was no significant difference between TG and 
CG ( $P>0.05)$, they were believed to have an impact on participant's antisocial behaviors by many researchers. Therefore, adult attachment styles were included in the logistic regression analysis as well.

In the next step, a binary logistic regression analysis was performed to identify risk factors for theft in men. The results showed that those who lived in urban area, whose family economic situation was relatively poor, who did not live with father before 5 years old, and whose parents had not divorced were more likely to commit theft $(P<0.05)$. On the contrary, participants who had no siblings and whose father was not alive were less likely to commit theft $(P<0.05)$. Results were shown in Table 2.

\section{Comparison Between First Offender Group and Recidivist Group}

To investigate risk factors for multiple thefts, the theft group was further divided into first offender group (FOG) and recidivist group (RG) according to their self-reported criminal records. Comparison of descriptive statistics for socio-demographic characteristics, family structures and adult attachment styles of FOG and RG were presented in Table 3.

There was no significant difference in long-term residency, family economic situation, having siblings or not, mother being alive or not, parents' marital status and adult attachment style between tow groups. But men in the FOG had a significantly higher proportion of living with mother/father before 5 years old and father alive than men in the RG $(P<0.05)$. All variables with $P<0.05$ and adult attachment styles were included in the subsequent logistic regression analysis.

\section{Risk Factors For Multiple Thefts}

When we conducted a binary logistic regression analysis with candidate parameters from last step, results suggested that men who did not live with mother before 5 years old and whose father was not alive were more likely to commit multiple thefts $(P<0.05)$. With secure attachment as the reference category, preoccupied attachment significantly decreased the risk of multiple thefts $(P<0.05)$, while fearful and dismissing attachment styles showed no significant effect $(P>0.05)$. See Table 4.

\section{Discussion}

By comparing the socio-demographic data, family structures and adult attachment styles between men with a conviction of theft and male college students, and analyzing their effects on theft, we found that there were significant difference in long-term residency, family economic situation, number of children, father's presence before 5years old, parents' state of living and parents' marital status. Moreover, living in urban area, from relatively poor family, not living with father before 5 years old and parents not divorced were risk factors for theft behaviors in men. While father not alive and having no siblings decreased the probability of theft in men.

In terms of social demographic factors, living in urban area increased men's theft risk, which may be related to the allocation of material resources in the region. In China, supplies in remote areas is only enough for daily use, not be hoarded in large quantities. People there usually engage in self-sufficient 
agriculture, and the population density is low (Tang et al., 2018). Accordingly, there are fewer goods and opportunities to steal than in urban areas. In addition, men from relatively poor families were more likely to commit theft, consistent with previous research that suggested material shortage and economic constraints were one of the reasons for theft (Harbaugh et al., 2013).

With respect to family structure, the presence of father and parents' marital status significantly affected theft in men. Many studies have found that fathers played an important role in establishing rules in children's growth (Langley, 2015; Habib et al., 2010). From the perspective of gender socialization, the relationship between son and father is more important than that between daughter and father (Root \& Rubin, 2010). Fathers have more severe punishment and interference protection for boys than girls. Compared with men whose father was present in the process of growth, men whose father was absent before the age of 5 had lower recognition of moral constraints and were therefore more likely to commit theft. In contrast, the results of this study suggested that men in adolescence and early adulthood with a deceased father were less likely to commit theft, possibly because they were more sensitive to the consequences of criminal risks since they needed to assume the family responsibilities previously undertaken by the father. As for parents' marital status, many studies on adolescent problem behaviors have shown that parental divorce was positively associated with violence and substance abuse (Weaver \& Schofield, 2015; Tebeka et al., 2016). On the contrary, results of this study showed that parents not divorced increased the risk for theft, which indicated that the psychological mechanisms for the occurrence and development of violence and theft were different.

Results of this study indicated that having no biological siblings, being the only child, decreased the probability of committing theft, which was consistent with previous studies. The Only-Child Policy of China, enacted in 1979, affected the way Chinese parents raised their children (Wang \& Fong, 2009). Resource dilution theory proposed that family resources, such as necessities of life and personal attention and intervention, are finite and divided by the number of children in a family (Blake, 1981). Only children received more attention and responsiveness from parents since childhood and parents of only children made more attempts to correct their only children than parents of multiple children, which help to facilitate children's development of psychological confidence and mature behavioral patterns (Liu et al., 2010). A cross-sectional study found that only children had better adjustments both psychologically and behaviorally at school in contrast to children with siblings, and presented lower level of psychological distress and delinquent participation, including stealing (Liu et al., 2017). In addition, as the sole heir to family property, being the only child is associated with taking less risk in economic behaviors (Cameron et al., 2013).

Theft group was then further divided into first offender group and recidivist group according to criminal records to analyze risk factors for multiple thefts. There were significant difference in presence of mother/father before 5 years old and father not alive. Furthermore, not living with mother before 5 years old and father not alive increased the possibility of multiple thefts, while preoccupied attachment decreased such possibility. 
The absence of mother in the process of growth is a specific trauma for children. Enough emotional support from mother reduces the occurrence of male adolescents' delinquency, otherwise it contributes to the formation of anti-social personality (VanderPyl, 2018). A longitudinal study revealed that a high quality initial mother-son relationship reduced youth's re-offending, consistent with our study (Cavanagh \& Cauffman, 2017). As mentioned earlier, death of the father was a protective factor for theft in general, but rather a risk factor for multiple thefts. The reason may be related to the economic pressure caused by father's death. Participants of this study were mainly adolescents and early adults. People of this age usually do not have qualified and stable livelihood ability. Multiple thefts may become the last choice under economic pressure.

Preoccupied attachment is characterized by high anxiety and low avoidance. Orehek et al.'s (2017) study found that anxious attachment was positively associated with higher assessment tendencies, and avoidant attachment was negatively associated with locomotion tendencies. This means that individuals with preoccupied attachment make their decisions based on assessment of means and consequences before initiating actions. In this way preoccupied attachment reduced the likelihood of multiple thefts.

There are some limitations to this study. First, participants were male only, so conclusions can't be generalized to other population. Second, first offenders and recidivists were divided according to their self-reported criminal records. It is possible that first offenders lie about their criminal records in case of privacy leakage and potential punishment.

\section{Conclusion}

This study provides important implications. Our findings show that risk factors for theft and multiple thefts were different. Family structure changes have a significant effect on theft behaviors in men and preoccupied attachment decreases the likelihood of multiple thefts in men. Various targeted measures are needed for preventing theft from occurring and reoccurring.

\section{Declarations}

\section{Ethics approval and consent to participate}

Ethical approval was granted by the Medical Ethics Committee of West China Hospital, Sichuan University. All methods were carried out in accordance with relevant guidelines and regulations.(eg. Helsinki declaration). Written informed consent was obtained from participants.

\section{Consent for publication}

Personal identifiers has been deleted from transcripts and findings were presented anonymously. Consent for publication was obtained.

\section{Availability of data and materials}


The datasets analyzed during the current study are available from the corresponding author on reasonable request.

\section{Competing interests}

No competing interests.

\section{Funding}

None.

\section{Authors' contributions}

Xu Wang and Jiajun Xu conducted the study. Xu Wang wrote the main manuscript and all authors reviewed the manuscript.

\section{Acknowledgements}

Not applicable.

\section{References}

1. Ainsworth, MDS. (1982). Attachment: Retrospect and prospect. In C. M. Parkes \& J. Stevenson-Hinde (Eds.).

2. American Psychiatric Association. (2013). Diagnostic and statistical manual of mental disorders, fifth edition (DSM-5). The SAGE Encyclopedia of Abnormal and Clinical Psychology.

3. Barker, E. D., Séguin, J. R., White, H. R., Bates, M. E., Lacourse, É., Carbonneau, R., \& Tremblay, R. E. (2007). Developmental trajectories of male physical violence and theft. Archives of General Psychiatry, 64(5), 592-599. https://doi.org/10.1001/archpsyc.64.5.592

4. Bartholomew, K., \& Horowitz, L. M. (1991). Attachment styles among young adults: A test of a fourcategory model. Journal of Personality and Social Psychology, 61(2), 226-244. https://doi.org/10.1037/0022-3514.61.2.226

5. Blake, J. (1981). Family size and the quality of children. Demography, 18(4), 421-442. https:// doi.org/10.2307/2060941

6. Blum, A. W., Odlaug, B. L., Redden, S. A., \& Grant, J. E. (2018). Stealing behavior and impulsivity in individuals with kleptomania who have been arrested for shoplifting. Comprehensive Psychiatry, 80 , 186-191. https://doi.org/10.1016/j.comppsych.2017.10.002

7. Bowlby, J. (1997). Attachment and loss: Attachment Volume 1. Pimlico.

8. Brazil, I., Van Dongen, J., Maes, J., Mars, R., \& Baskin-Sommers, A. (2018). Classification and treatment of antisocial individuals: From behavior to biocognition. Neuroscience \& Biobehavioral Reviews, 91, 259-277. https://doi.org/10.1016/j.neubiorev.2016.10.010 
9. Brennan, K. A., Clark, C. L., Shaver, P. R. (1998). Self-report measurement of adult attachment: An integrative overview. In Simpson J.A. \& Rholes W Seds.

10. Cameron, L., Erkal, N., Gangadharan, L., \& Meng, X. (2013). Little emperors: Behavioral impacts of China's one-child policy. Science, 339(6122), 953-957. https://doi.org/10.1126/science.1230221

11. Cavanagh, C., \& Cauffman, E. (2017). The longitudinal association of relationship quality and reoffending among first-time juvenile offenders and their mothers. Journal of Youth and Adolescence, 46(7), 1533-1546. https://doi.org/10.1007/s10964-017-0679-3

12. Cheung, N. W. (2012). Low self-control and Co-occurrence of gambling with substance use and delinquency among Chinese adolescents. Journal of Gambling Studies, 30(1), 105-124. https://doi.org/10.1007/s10899-012-9351-8

13. Fearon, R. P., Bakermans-Kranenburg, M. J., Van IJzendoorn, M. H., Lapsley, A., \& Roisman, G. I. (2010). The significance of insecure attachment and disorganization in the development of children's externalizing behavior: A meta-analytic study. Child Development, 81(2), 435-456. https://doi.org/10.1111/j.1467-8624.2009.01405.x

14. Fraley, R. C., Hudson, N. W., Heffernan, M. E., \& Segal, N. (2015). Are adult attachment styles categorical or dimensional? A taxometric analysis of general and relationship-specific attachment orientations. Journal of Personality and Social Psychology, 109(2), 354-368. https://doi.org/10.1037/pspp0000027

15. Groh, A. M., Fearon, R. P., Bakermans-Kranenburg, M. J., Van IJzendoorn, M. H., Steele, R. D., \& Roisman, G. I. (2014). The significance of attachment security for children's social competence with peers: A meta-analytic study. Attachment \& Human Development, 16(2), 103-136. https://doi.org/10.1080/14616734.2014.883636

16. Habib, C., Santoro, J., Kremer, P., Toumbourou, J., Leslie, E., \& Williams, J. (2010). The importance of family management, closeness with father and family structure in early adolescent alcohol use. Addiction, 105(10), 1750-1758. https://doi.org/10.1111/j.1360-0443.2010.03021.x

17. Hu, D. F.(2019). The theft crime and its system status in crimes of property violation. The Jurist, (5):113-127.

18. Harbaugh, W. T., Mocan, N., \& Visser, M. S. (2013). Theft and deterrence. Journal of Labor Research, 34(4), 389-407. https://doi.org/10.1007/s12122-013-9169-x

19. Langley, C. (2015). Father knows best: Paternal presence and sexual debut in African-American adolescents living in poverty. Family Process, 55(1), 155-170. https://doi.org/10.1111/famp.12125

20. Lee, D., Han, Y., Park, M., \& Roh, S. (2015). Psychological, family, and social factors linked with juvenile theft in Korea. School Psychology International, 36(6), 648-670. https://doi.org/10.1177/0143034315604184

21. Li, T. G., \& Jiateng, H. S.(2006). Measure of adult attachment: Experiences in Close Relationship Inventory (ECR) Chinese Version. Acta Psychologica Sinica, 38(3):399-406.

22. Liu, H. B., \& Gao, Y.C.(2018). Research on current theft crimes in China. Journal of People's Public Security University of China (Social Sciences Edition), 192(02):63-71. 
23. Liu, N., Chen, Y., Yang, X., \& Hu, Y. (2017). Do demographic characteristics make differences? Demographic characteristics as moderators in the associations between only child status and cognitive/non-cognitive outcomes in China. Frontiers in Psychology, 8, 423. https://doi.org/10.3389/fpsyg.2017.00423

24. Liu, R. X., Lin, W., \& Chen, Z. (2009). The effect of parental responsiveness on differences in psychological distress and delinquency between Singleton and Non-Singleton Chinese adolescents. Journal of Child and Family Studies, 19(5), 547-558. https://doi.org/10.1007/s10826-009-9329-z

25. Murray, J., Shenderovich, Y., Gardner, F., Mikton, C., Derzon, J. H., Liu, J., \& Eisner, M. (2018). Risk factors for antisocial behavior in low- and middle-income countries: A systematic review of longitudinal studies. Crime and Justice, 47(1), 255-364. https://doi.org/10.1086/696590

26. Orehek, E., Vazeou-Nieuwenhuis, A., Quick, E., \& Weaverling, G. C. (2017). Attachment and SelfRegulation. Personality \& social psychology bulletin, 43(3), 365-380. https://doi.org/10.1177/0146167216685292

27. Próspero-Luis, J., Moreira, P. S., Paiva, T. O., Teixeira, C. P., Costa, P., \& Almeida, P. R. (2017). Psychopathy, criminal intentions, and abnormal appraisal of the expected outcomes of theft. Legal and Criminological Psychology, 22(2), 314-331. https://doi.org/10.1111/lcrp.12103

28. Root, A. K., \& Rubin, K. H. (2010). Gender and parents' reactions to children's emotion during the preschool years. New Directions for Child and Adolescent Development, 2010(128), 51-64. https://doi.org/10.1002/cd.268

29. Sipowicz, J., \& Kujawski, R. (2018). Kleptomania or common theft - diagnostic and judicial difficulties. Psychiatria Polska, 52(1), 81-92. https://doi.org/10.12740/pp/82196

30. Sobotková, V., Blatný, M., Jelínek, M., \& Hrdlička, M. (2012). Antisocial behavior in adolescence. The Journal of Early Adolescence, 33(8), 1091-1115. https://doi.org/10.1177/0272431612445377

31. Tang, P., Yang, S., \& Boehe, D. (2018). Ownership and corporate social performance in China: Why geographic remoteness matters. Journal of Cleaner Production, 197, 1284-1295. https://doi.org/10.1016/j.jclepro.2018.06.288

32. Tebeka, S., Hoertel, N., Dubertret, C., \& Le Strat, Y. (2016). Parental divorce or death during childhood and adolescence and its association with mental health. Journal of Nervous \& Mental Disease, 204(9), 678-685. https://doi.org/10.1097/nmd.0000000000000549

33. VanderPyl, T. (2018). "I wanna make my mom proud of me": Embracing mothers as protective factors against future offending in delinquent youth. Juvenile and Family Court Journal, 69(3), 6579. https://doi.org/10.1111/jfcj. 12117

34. Wang, M., Dishion, T. J., Stormshak, E. A., \& Willett, J. B. (2011). Trajectories of family management practices and early adolescent behavioral outcomes. Developmental Psychology, 47(5), 1324-1341. https://doi.org/10.1037/a0024026

35. Wang, Y., \& Fong, V. L. (2009). Little emperors and the 4:2:1 generation: China's singletons. Journal of the American Academy of Child \& Adolescent Psychiatry, 48(12), 1137-1139. https://doi.org/10.1097/chi.0b013e3181bc72f8 
36. Weaver, J. M., \& Schofield, T. J. (2015). Mediation and moderation of divorce effects on children's behavior problems. Journal of Family Psychology, 29(1), 39-48.

https://doi.org/10.1037/fam0000043

37. Weng, X., Ran, M., \& Chui, W. H. (2016). Juvenile delinquency in Chinese adolescents: An ecological review of the literature. Aggression and Violent Behavior, 31, 26-36.

https://doi.org/10.1016/j.avb.2016.06.016

38. Zhang, Z., Huang, F., \& Liu, D. (2018). Kleptomania: Recent advances in symptoms, etiology and treatment. Current Medical Science, 38(5), 937-940. https://doi.org/10.1007/s11596-018-1966-2

\section{Tables}


Table 1

Socio-demographic characteristics, family structure, and adult attachment style of TG and CG

\begin{tabular}{|c|c|c|c|c|c|}
\hline \multirow[t]{2}{*}{ Variables } & & \multicolumn{2}{|c|}{$(M \pm S D) / \%$} & \multirow{2}{*}{$\begin{array}{l}t(d f) / \\
x^{2}\end{array}$} & \multirow[t]{2}{*}{$\mathbf{P}$} \\
\hline & & $\begin{array}{l}\text { TG } \\
(n=257)\end{array}$ & $\begin{array}{l}\text { CG } \\
(n=405)\end{array}$ & & \\
\hline Age & & $\begin{array}{l}22.42 \pm \\
2.62\end{array}$ & $\begin{array}{l}22.78 \pm \\
2.58\end{array}$ & 1.740 & 0.082 \\
\hline \multirow[t]{3}{*}{ Long-term residency } & Urban area & 42 & 164 & \multirow[t]{3}{*}{45.288} & \multirow{3}{*}{$<.001 *$} \\
\hline & Suburb area & 165 & 169 & & \\
\hline & Remote area & 50 & 72 & & \\
\hline \multirow[t]{4}{*}{ Family economic situation } & Very poor & 32 & 34 & \multirow[t]{4}{*}{12.445} & \multirow[t]{4}{*}{$0.006^{*}$} \\
\hline & $\begin{array}{l}\text { Relatively } \\
\text { poor }\end{array}$ & 41 & 105 & & \\
\hline & Average & 164 & 225 & & \\
\hline & Well-off & 30 & 41 & & \\
\hline \multirow[t]{2}{*}{ Have siblings } & Yes & 52 & 165 & \multirow[t]{2}{*}{30.008} & \multirow{2}{*}{$<.001 *$} \\
\hline & No & 205 & 240 & & \\
\hline \multirow{2}{*}{$\begin{array}{l}\text { Lived with mother before } 5 \text { years } \\
\text { old }\end{array}$} & Yes & 234 & 359 & \multirow[t]{2}{*}{0.977} & \multirow[t]{2}{*}{0.323} \\
\hline & No & 23 & 46 & & \\
\hline \multirow{2}{*}{$\begin{array}{l}\text { Lived with father before } 5 \text { years } \\
\text { old }\end{array}$} & Yes & 235 & 342 & \multirow[t]{2}{*}{6.875} & \multirow[t]{2}{*}{$0.009 *$} \\
\hline & No & 22 & 63 & & \\
\hline \multirow[t]{2}{*}{ Mother alive } & Yes & 224 & 388 & \multirow[t]{2}{*}{16.821} & \multirow{2}{*}{$<.001 *$} \\
\hline & No & 33 & 17 & & \\
\hline \multirow[t]{2}{*}{ Father alive } & Yes & 216 & 383 & \multirow[t]{2}{*}{20.212} & \multirow{2}{*}{$<.001 *$} \\
\hline & No & 41 & 22 & & \\
\hline \multirow[t]{2}{*}{ Parents divorced } & Yes & 36 & 19 & \multirow[t]{2}{*}{17.914} & \multirow{2}{*}{$<.001 *$} \\
\hline & No & 221 & 386 & & \\
\hline \multirow[t]{2}{*}{ Adult attachment style } & Secure & 23 & 50 & \multirow[t]{2}{*}{6.178} & \multirow[t]{2}{*}{0.103} \\
\hline & Fearful & 146 & 195 & & \\
\hline * indicates $P<0.05$ & & & & & \\
\hline
\end{tabular}




\begin{tabular}{|c|c|c|c|c|c|}
\hline \multirow[t]{2}{*}{ Variables } & & \multicolumn{2}{|c|}{$(M \pm S D) / \%$} & \multirow{2}{*}{$\begin{array}{l}t(d f) / \\
x^{2}\end{array}$} & \multirow[t]{2}{*}{$\mathbf{P}$} \\
\hline & & $\begin{array}{l}\text { TG } \\
(n=257)\end{array}$ & $\begin{array}{l}\text { CG } \\
(n=405)\end{array}$ & & \\
\hline & Preoccupied & 40 & 82 & & \\
\hline & Dismissing & 48 & 78 & & \\
\hline * indicates $P<0.05$ & & & & & \\
\hline
\end{tabular}


Table 2

Binary logistic regression of socio-demographic characteristics, family structures and adult attachment styles of overall sample

\begin{tabular}{|c|c|c|c|c|c|c|}
\hline Variables & & B & S.E. & $\operatorname{Exp}(B)$ & $95 \% \mathrm{Cl}$ & $\mathbf{P}$ \\
\hline \multirow[t]{3}{*}{ Long-term residency } & Urban area & 1.060 & 0.308 & 2.887 & $\begin{array}{l}1.580 \sim \\
5.277\end{array}$ & $0.001 *$ \\
\hline & Suburb area & -0.248 & 0.251 & 0.780 & $\begin{array}{l}0.477 \sim \\
1.277\end{array}$ & 0.324 \\
\hline & Remote area & - & - & - & - & - \\
\hline \multirow[t]{4}{*}{ Family economic situation } & Very poor & 0.030 & 0.446 & 1.031 & $\begin{array}{l}0.430 \sim \\
2.472\end{array}$ & 0.946 \\
\hline & $\begin{array}{l}\text { Relatively } \\
\text { poor }\end{array}$ & 0.808 & 0.391 & 2.244 & $\begin{array}{l}1.044 \sim \\
4.824\end{array}$ & $0.039 *$ \\
\hline & Average & -0.151 & 0.341 & 0.860 & $\begin{array}{l}0.441 \sim \\
1.678\end{array}$ & 0.657 \\
\hline & Well-off & - & - & - & - & - \\
\hline \multirow[t]{2}{*}{ Have siblings } & Yes & - & - & - & - & - \\
\hline & No & -0.83 & 0.212 & 0.435 & $\begin{array}{l}0.287 \sim \\
0.658\end{array}$ & $<.001 *$ \\
\hline \multirow{2}{*}{$\begin{array}{l}\text { Lived with father before } 5 \\
\text { years old }\end{array}$} & Yes & - & - & - & - & - \\
\hline & No & 0.673 & 0.297 & 1.961 & $\begin{array}{l}1.096 \sim \\
3.507\end{array}$ & $0.023 *$ \\
\hline \multirow[t]{2}{*}{ Mother alive } & Yes & - & - & - & - & - \\
\hline & No & -0.506 & 0.365 & 0.603 & $\begin{array}{l}0.295 \sim ~ \\
1.233\end{array}$ & 0.165 \\
\hline \multirow[t]{2}{*}{ Father alive } & Yes & - & - & - & - & - \\
\hline & No & -1.108 & 0.328 & 0.330 & $\begin{array}{l}0.173 \sim \\
0.628\end{array}$ & $0.001 *$ \\
\hline \multirow[t]{2}{*}{ Parents divorced } & Yes & - & - & - & - & - \\
\hline & No & 1.641 & 0.351 & 5.159 & $\begin{array}{l}2.591 \sim \\
10.273\end{array}$ & $\stackrel{<}{0.001 *}$ \\
\hline \multirow[t]{2}{*}{ Adult attachment styles } & Secure & 0.296 & 0.341 & 1.345 & $\begin{array}{l}0.690 \sim \\
2.623\end{array}$ & 0.384 \\
\hline & Fearful & -0.163 & 0.236 & 0.849 & $\begin{array}{l}0.534 \sim \\
1.350\end{array}$ & 0.489 \\
\hline
\end{tabular}

* indicates $\mathrm{P}<0.05$ 


\begin{tabular}{|lllllll|}
\hline Variables & & B & S.E. & Exp(B) & $95 \% C l$ & P \\
\hline & Preoccupied & 0.208 & 0.295 & 1.231 & $0.690 \sim$ & 0.482 \\
& & & & & 2.196 & \\
\hline * indicates $\mathrm{P}<0.05$ & Dismissing & - & - & - & - & - \\
\hline
\end{tabular}


Table 3

Socio-demographic data, family structure, and adult attachment style of FOG and RG

\begin{tabular}{|c|c|c|c|c|c|}
\hline \multicolumn{2}{|l|}{ Variables } & \multirow{2}{*}{$\begin{array}{l}\text { FOG } \\
(n=165) \\
21\end{array}$} & \multirow{2}{*}{$\begin{array}{l}\text { RG } \\
(n=92)\end{array}$} & \multirow{2}{*}{$\begin{array}{l}x^{2} \\
5.121\end{array}$} & \multirow{2}{*}{$\begin{array}{l}\mathbf{P} \\
0.077\end{array}$} \\
\hline Long-term residency & Urban area & & & & \\
\hline & Suburb area & 108 & 57 & & \\
\hline & Remote area & 36 & 14 & & \\
\hline \multirow[t]{4}{*}{ Family economic situation } & Very poor & 18 & 14 & 2.933 & 0.402 \\
\hline & Relatively poor & 23 & 18 & & \\
\hline & Average & 110 & 54 & & \\
\hline & Well-off & 14 & 6 & & \\
\hline \multirow[t]{2}{*}{ Have siblings } & Yes & 136 & 70 & 1.491 & 0.222 \\
\hline & No & 29 & 22 & & \\
\hline \multirow[t]{2}{*}{ Lived with mother before 5 years old } & Yes & 159 & 75 & 15.968 & $<0.001^{*}$ \\
\hline & No & 6 & 17 & & \\
\hline \multirow[t]{2}{*}{ Lived with father before 5 years old } & Yes & 158 & 77 & 10.979 & $0.002^{*}$ \\
\hline & No & 7 & 15 & & \\
\hline \multirow[t]{2}{*}{ Mother alive } & Yes & 148 & 76 & 2.652 & 0.103 \\
\hline & No & 17 & 16 & & \\
\hline \multirow[t]{2}{*}{ Father alive } & Yes & 148 & 68 & 10.975 & $0.001^{*}$ \\
\hline & No & 17 & 24 & & \\
\hline \multirow[t]{2}{*}{ Parents divorced } & Yes & 18 & 18 & 3.674 & 0.062 \\
\hline & No & 147 & 74 & & \\
\hline \multirow[t]{4}{*}{ Adult attachment style } & Secure & 11 & 12 & 3.251 & 0.354 \\
\hline & Fearful & 95 & 52 & & \\
\hline & Preoccupied & 27 & 12 & & \\
\hline & Dismissing & 32 & 16 & & \\
\hline
\end{tabular}


Table 4

Binary logistic regression of socio-demographic characteristics, family structures and adult attachment styles of theft group

\begin{tabular}{|c|c|c|c|c|c|c|}
\hline Variables & & B & S.E. & $\operatorname{Exp}(B)$ & $95 \% \mathrm{Cl}$ & $\mathbf{P}$ \\
\hline \multirow{2}{*}{$\begin{array}{l}\text { Lived with mother before } 5 \\
\text { years old }\end{array}$} & Yes & - & - & - & - & - \\
\hline & No & 1.600 & 0.601 & 4.536 & $\begin{array}{l}1.397 \sim \\
14.732\end{array}$ & $0.012^{*}$ \\
\hline \multirow{2}{*}{$\begin{array}{l}\text { Lived with father before } 5 \text { years } \\
\text { old }\end{array}$} & Yes & - & - & - & - & - \\
\hline & No & 0.600 & 0.598 & 1.778 & $\begin{array}{l}0.551 \sim \\
5.739\end{array}$ & 0.336 \\
\hline \multirow[t]{2}{*}{ Father alive } & Yes & - & - & - & - & - \\
\hline & No & 1.260 & 0.359 & 3.130 & $\begin{array}{l}1.549 \sim \\
6.325\end{array}$ & $0.001 *$ \\
\hline \multirow[t]{4}{*}{ Adult attachment styles } & Secure & - & - & - & - & - \\
\hline & Fearful & -0.985 & 0.537 & 0.374 & $\begin{array}{l}0.131 \sim \\
1.069\end{array}$ & 0.066 \\
\hline & Preoccupied & -1.116 & 0.475 & 0.328 & $\begin{array}{l}0.129 \sim \\
0.831\end{array}$ & $0.019 *$ \\
\hline & Dismissing & -1.076 & 0.564 & 0.341 & $\begin{array}{l}0.113 \sim \\
1.029\end{array}$ & 0.056 \\
\hline
\end{tabular}

